\title{
Poly(ADP-ribose)polymerase activation determines strain sensitivity to streptozotocin-induced $\beta$ cell death in inbred mice
}

\author{
J W Cardinal ${ }^{1}$, D J Allan ${ }^{2}$ and D P Cameron ${ }^{1}$ \\ ${ }^{1}$ Department of Diabetes and Endocrinology, Princess Alexandra Hospital, Ipswich Road, \\ Woolloongabba, Brisbane, 4102, Australia \\ ${ }^{2}$ School of Life Sciences, Queensland University of Technology, Brisbane, 4000, Australia \\ (Requests for offprints should be addressed to J W Cardinal)
}

\begin{abstract}
Streptozotocin (STZ) is believed to induce pancreatic $\beta$ cell death in mice by depleting the cell of $\mathrm{NAD}+\mathrm{NADH}$. The drug is known to cause a greater depletion of $\beta$ cell $\mathrm{NAD}+\mathrm{NADH}$ in $\mathrm{C} 57 \mathrm{bl} / 6 \mathrm{~J}$ mice than in Balb/c mice. To investigate the basis for this strain difference, we compared the effects of streptozotocin on poly(ADP-ribose)polymerase (PARP) activation - the major site of NAD consumption, and on mitochondrial activity - the major site of NAD production.

A significant strain difference was demonstrated in STZ-induced PARP activation (fmol NAD incorporated $/ \mathrm{min} / \mu \mathrm{g}$ DNA \pm s.E.M.: Balb/c control $2 \cdot 28 \pm 0 \cdot 14$, Balb STZ $3 \cdot 11 \pm 0 \cdot 25 ;$ C $57 \mathrm{bl} / 6 \mathrm{~J}$ control $2 \cdot 57 \pm 0 \cdot 29, \mathrm{C} 57 \mathrm{bl} / 6 \mathrm{~J} \mathrm{STZ} 4 \cdot 17 \pm 0 \cdot 24)$. In comparison, no strain difference could be demonstrated in hydrogen-peroxide-induced PARP activation. No strain differences could be detected in the activity of STZ-treated islet mitochondria as measured by determining ATP production (pmol/ $\mu \mathrm{g}$ protein/h \pm s.E.M.: Balb/c control 0.20 \pm 0.02 ,
\end{abstract}

Balb/c STZ 0.15 $\pm 0 \cdot 02 ; \mathrm{C} 57 \mathrm{bl} / 6 \mathrm{~J}$ control $0 \cdot 23 \pm$ $0 \cdot 03, \mathrm{C} 57 \mathrm{bl} / 6 \mathrm{~J} \mathrm{STZ} 0 \cdot 15 \pm 0 \cdot 02)$ or by $3-[4,5-$ dimethylthiazol-2-yl]-2,5-diphenyltetrazolium bromide (MTT) dye reduction (change in optical density/mg protein \pm s.E.M.: Balb/c control 10.19 \pm $0 \cdot 62$, Balb/c STZ 6.01 $\pm 1 \cdot 17 ; \mathrm{C} 57 \mathrm{bl} / 6 \mathrm{~J}$ control $6 \cdot 15 \pm 0 \cdot 98, \mathrm{C} 57 \mathrm{bl} / 6 \mathrm{~J} \mathrm{STZ} 5 \cdot 81 \pm 0 \cdot 96$ ).

The strain difference in STZ-induced NAD depletion appears to be due to a difference in NAD consumption and not a difference in a mitochondrial process involved in replacing decreasing NAD concentrations. It is unlikely that a strain difference in the enzymic activity of PARP is responsible for strain differences in the effects of STZ, as no strain differences in hydrogen-peroxide-induced PARP activation could be detected. Thus the greater PARP activation, NAD depletion and $\beta$ cell death observed in $\mathrm{C} 57 \mathrm{bl} / 6 \mathrm{~J}$ islets may be due to greater levels of DNA damage or differences in the DNA excision repair processes.

Fournal of Molecular Endocrinology (1999) 22, 65-70

\section{INTRODUCTION}

The drug streptozotocin (STZ) is a glucose analogue (N-[methylnitrosocarbamoyl]-D-glucosamine) that specifically damages pancreatic $\beta$ cells (Schein \& Loftus 1968). It is rapidly transported into the $\beta$ cell via the glucose transporter, Glut2, and is known to be metabolised by the $\beta$ cell upon entry (Karunanayake et al. 1976, Johansson \& Tjalve 1989, Kroncke et al. 1995). STZ metabolites accumulate inside the cell, presumably because the glucose moiety is lost. STZ then acts on the cellular components and, in particular, the mitochondria and DNA (Schein et al. 1973, Kwon et al. 1994).
STZ acts on the mitochondria by inhibiting the ability to produce ATP and, in the process, NAD. The major action of STZ on the DNA is believed to be the induction of DNA adducts (Ledoux et al. 1988). These adducts are in turn repaired by the nuclear excision repair processes. The strand breaks induced during excision repair activate poly(ADPribose)polymerase (PARP), which converts NAD into polymers of ADP-ribose at the site of the DNA strand break (Yamamoto et al. 1981). This leads to NAD depletion. If the DNA repair processes are sufficiently activated, PARP activation can cause the depletion of NAD to non-physiological levels. Normally NAD depletion would be replaced by 
cellular processes. However, STZ also inhibits the replacement of the NAD by inhibiting mitochondrial ATP generation. Thus, both DNA repairinduced NAD depletion and the inability of the cell to replace decreasing NAD concentrations may combine to cause loss of cell viability.

Inbred strains of mice vary in their sensitivity to STZ injected as a single dose or as multiple subdiabetogenic doses (Rossini et al. 1977). This indicates that genetic susceptibility to the initial $\beta$-cell-damaging event seen after a single dose of STZ may contribute to the progression of insulindependent diabetes mellitus in the multiple-lowdose STZ mouse model. Previous studies in this laboratory (Cardinal et al. 1998) have investigated the basis for differences in STZ sensitivity between the sensitive $\mathrm{C} 57 \mathrm{bl} / 6 \mathrm{~J}$ and the relatively resistant Balb/c mouse strains. Balb/c mice contained over seven times more pancreatic insulin than $\mathrm{C} 57 \mathrm{bl} / 6 \mathrm{~J}$ mice after an i.v. dose of $120 \mathrm{mg} / \mathrm{kg}$ body weight. The difference in STZ sensitivity was due to the amount of $\beta$ cell death as confirmed by morphology in in vivo studies. STZ sensitivity was found to be at the $\beta$ cell level, as $\mathrm{C} 57 \mathrm{bl} / 6 \mathrm{~J}$ islets incubated in vitro contained over 14 times more dead cells. After an in vitro dose of $2 \cdot 2 \mathrm{mM} \mathrm{STZ} \mathrm{for}$ $30 \mathrm{~min}$, islet concentrations of NAD were significantly less in $\mathrm{C} 57 \mathrm{bl} / 6 \mathrm{~J}$ islets than in Balb/c islets. As no strain differences in STZ/glucose transporter capacity could be detected, these studies concluded that STZ sensitivity is determined at the $\beta$ cell level and is regulated by events that occur after the drug enters the $\beta$ cell and before the cell is depleted of NAD. The present study examined whether the strain differences in STZ sensitivity and NAD depletion are due to a greater consumption of NAD by the DNA repair enzyme PARP, or to a difference in the ability to replace the decreasing ATP and NAD levels by the mitochondria.

\section{MATERIALS AND METHODS}

\section{Mice and reagents}

Male Balb/c and C57bl/6J mice were obtained from the Central Animal Breeding House at the University of Queensland. The animals were 8-12 weeks old at the start of each experiment. All animal experimentation was approved by the Queensland University of Technology Research Ethics Committee and was in compliance with the National Health and Medical Research Council code of practice for the care and use of animals for scientific purposes.

\section{Islet isolation}

Islets were isolated using the method of Lake et al. (1987). Using this method, 100-200 islets per mouse could be reliably isolated.

\section{Isolation of islet nuclei and mitochondria}

All islets used for isolation of nuclei and mitochondria were prepared using previously described methods (Eizirik et al. 1988). After treatment, the islets were washed in Hank's buffered saline solution supplemented with $0 \cdot 2 \%$ bovine serum albumin, $5.5 \mathrm{mM}$ D-glucose and $20 \mathrm{mM}$ Hepes (HBSSH) and resuspended in a solution containing $250 \mathrm{mM}$ sucrose, $2.5 \mathrm{mM}$ EDTA, $2 \mathrm{mM}$ cysteine, $0.02 \%$ bovine serum albumin, $10 \mathrm{mM}$ Hepes $\mathrm{pH}$ 7.4. The islets were left to lyse partially in this buffer for $5 \mathrm{~min}$ on ice and then dispersed by rapidly pipetting the solution in and out of a 1-ml pipette 20 times. The nuclei were pelleted by centrifuging for $3 \mathrm{~min}$ at $1000 \mathrm{~g}$. The pellet was then used for PARP activity assays. The supernatant was retained and further spun at $100000 \mathrm{~g}$ for $5 \mathrm{~min}$ at $4{ }^{\circ} \mathrm{C}$ in a Beckman TL-100 ultracentrifuge. The pellet was used for mitochondrial activity assays.

\section{Estimation of poly(ADP-ribose)polymerase (PARP) activity}

The method used was a modification of that of Uchigata et al. (1982). Nuclei from 150 islets (one mouse) were resuspended in $100 \mu \mathrm{l}$ buffer A (50 mM Tris $\mathrm{pH} 7 \cdot 5,30 \%$ glycerol, $1 \mathrm{mM}$ EDTA, $0.5 \mathrm{mM}$ EGTA) and $100 \mu \mathrm{l}$ buffer B $(100 \mathrm{mM}$ Tris $\mathrm{pH} \quad 8 \cdot 0, \quad 10 \mathrm{mM} \quad \mathrm{MgCl}_{2}, 5 \mu \mathrm{Ci} / \mathrm{ml}$ [adenine-2,8$\left.{ }^{3} \mathrm{H}\right] \mathrm{NAD}$ (NEN), $20 \mathrm{mM} \beta$ mercaptoethanol). The mixture was vortexed and incubated for $30 \mathrm{~min}$ at $37^{\circ} \mathrm{C}$. The DNA was precipitated by adding $1 \mathrm{ml}$ ice-cold stop solution (10\% trichloroacetic acid, $2 \%$ sodium pyrophosphate decahydrate). The samples were left on ice for $45 \mathrm{~min}$ and then spun at $12000 \mathrm{~g}$ in a microfuge for $10 \mathrm{~min}$. The supernatant was removed and the pellet was washed three more times with $1 \mathrm{ml}$ stop solution, followed by one wash in $0.6 \mathrm{M}$ perchloric acid. The pellet was then left to resuspend overnight in $200 \mu \mathrm{l} 0.04 \mathrm{M} \mathrm{NaOH}$. A portion $(150 \mu \mathrm{l})$ of the solution was added to $10 \mathrm{ml}$ Instagel scintillant and the amount of radioactivity measured in a $\beta$ counter. The remainder of the sample was used to measure DNA content as previously described (Kissane \& Robins 1958). Results were expressed as fmol NAD incorporated/ $\min / \mu \mathrm{g}$ DNA. 


\section{Assessment of STZ effects on mitochondrial ATP content and ATP production}

Groups of 50 islets (one mouse) were incubated with $2 \cdot 2 \mathrm{mM}$ STZ for $30 \mathrm{~min}$ in $1 \mathrm{ml}$ HBSSH. The islets were washed with $\mathrm{HBSSH}$, mitochondria isolated and the pellet resuspended in $200 \mu \mathrm{l} 0 \cdot 1 \mathrm{M}$ phosphate buffer that had previously been gassed for $5 \mathrm{~min}$ with carbogen $\left(5 \% \mathrm{CO}_{2}\right.$ in $\left.\mathrm{O}_{2}\right)$. One hundred microlitres of the suspension were added to $100 \mu \mathrm{l}$ reaction buffer $(50 \mathrm{mM}$ NAD, $0 \cdot 2 \mathrm{mM}$ L-glutamic acid sodium salt, $0.25 \mathrm{mM}$ ADP in $0 \cdot 1 \mathrm{M}$ phosphate buffer $\mathrm{pH} 7 \cdot 4$ ), mixed and incubated at $37^{\circ} \mathrm{C}$. At time points $0,1,2$ and $3 \mathrm{~h}, 50 \mu \mathrm{l}$ was removed, added to $50 \mu$ l boiling stop buffer (100 mM Tris pH 7·8, $4 \mathrm{mM}$ EDTA), boiled for $2 \mathrm{~min}$ and placed on ice until assayed for ATP. Ten microlitres of this mixture were added to $100 \mu$ luciferase reagent and the luminescence read using a Packard Picolite luminometer. The sample was read for $10 \mathrm{~s}$ after a $2 \mathrm{~s}$ delay. The ATP standard curve was constructed between 1 and $10 \mathrm{mM}$. Sample ATP concentrations were read off a $\log$ luminescence vs $\log$ concentration standard curve. Samples were expressed as pmol ATP/ $\mu \mathrm{g}$ protein. Protein was measured using the Bradford method (1976).

\section{Assessment of STZ effects on mitochondrial MTT dye reduction}

Mitochondria from 150 islets (one mouse) were resuspended in $150 \mu \mathrm{l} 0 \cdot 1 \mathrm{M}$ phosphate buffer $\mathrm{pH} 7 \cdot 4$. A portion of this suspension $(50 \mu \mathrm{l})$ was used to measure protein content using the method of Bradford (1976). The mitochondrial suspension $(50 \mu \mathrm{l})$ was added to $50 \mu \mathrm{l}$ MTT reaction solution $(0.5 \mathrm{mg} / \mathrm{ml} \quad \mathrm{MTT}, \quad 50 \mathrm{mM} \quad \mathrm{NAD}, \quad 0.2 \mathrm{mM}$ L-glutamic acid sodium salt, $50 \mathrm{mM}$ ADP in $0 \cdot 1 \mathrm{M}$ phosphate buffer $\mathrm{pH} \mathrm{7.4)}$ and incubated at $37^{\circ} \mathrm{C}$. Dye reduction was measured at $30 \mathrm{~min}$ and $60 \mathrm{~min}$. The reaction was stopped by adding $500 \mu \mathrm{l}$ isopropanol. The dye was allowed to dissolve overnight at $4{ }^{\circ} \mathrm{C}$. The contents were then centrifuged at $12000 \mathrm{~g}$ in a microcentrifuge for $10 \mathrm{~min}$. The supernatant was read in a Shimadzu UV1601 spectrophotometer at $540 \mathrm{~nm}$. The rate of change in absorbance from $30 \mathrm{~min}$ to $60 \mathrm{~min}$ was proportional to the mitochondrial dehydrogenase activity. Activity was expressed as change in optical density and corrected for protein content.

\section{Statistical analysis methods}

Results from groups from each study were first analysed using ANOVA (using the statistical software package 'Statistical Package for Social
Sciences (SPSS) Version 7·5'). If the ANOVA showed a significant difference between groups, Student's $t$-test was used as the post hoc test.

\section{RESULTS}

\section{Poly(ADP-ribose)polymerase activation assay}

PARP activation was measured after groups of 150 islets from both strains were treated with $2 \cdot 2 \mathrm{mM}$ STZ or $200 \mu \mathrm{M}$ hydrogen peroxide for $30 \mathrm{~min}$. STZ significantly increased islet PARP activation in both strains, with the level of PARP activation being significantly greater in $\mathrm{C} 57 \mathrm{bl} / 6 \mathrm{~J}$ islets (Fig. 1a). There was no significant difference in control PARP activity in islets from the two strains. Hydrogen peroxide also increased islet PARP activation in both strains, however there was no strain difference detected (Fig. 1b).

\section{Mitochondrial ATP content}

Mitochondrial ATP content was measured after groups of 50 islets were treated with $2 \cdot 2 \mathrm{mM} \mathrm{STZ}$ for $30 \mathrm{~min}$. There were no significant differences in mitochondrial ATP content between control and STZ-treated islets from both strains. There were also no significant differences between strains in mitochondrial ATP content for both control and STZ-treated islets (Fig. 2).

\section{Mitochondrial activity}

Islet mitochondrial activity was measured after islets were treated with $2.2 \mathrm{mM}$ STZ for $30 \mathrm{~min}$. Mitochondrial activity, as measured by ATP production, decreased significantly in $\mathrm{C} 57 \mathrm{bl} / 6 \mathrm{~J}$ islets $(P<0 \cdot 05)$, but not in Balb/c islets, after treatment with STZ (Fig. 3). However, no strain difference in islet mitochondrial ATP production was detected between the two strains after STZ treatment.

Using the MTT dye reduction assay, mitochondrial activity from control Balb/c islets was significantly greater than that from $\mathrm{C} 57 \mathrm{bl} / 6 \mathrm{~J}$ islets $(P<0 \cdot 01)$. After streptozotocin treatment, there was no significant difference between strains (Fig. 4).

\section{DISCUSSION}

This study demonstrated a significantly greater activation of PARP in the islets of $\mathrm{C} 57 \mathrm{bl} / 6 \mathrm{~J}$ mice than in those of Balb/c mice in response to STZ treatment. There was no significant difference in mitochondrial ATP content or activity in STZtreated islets between the two strains. Thus it is 

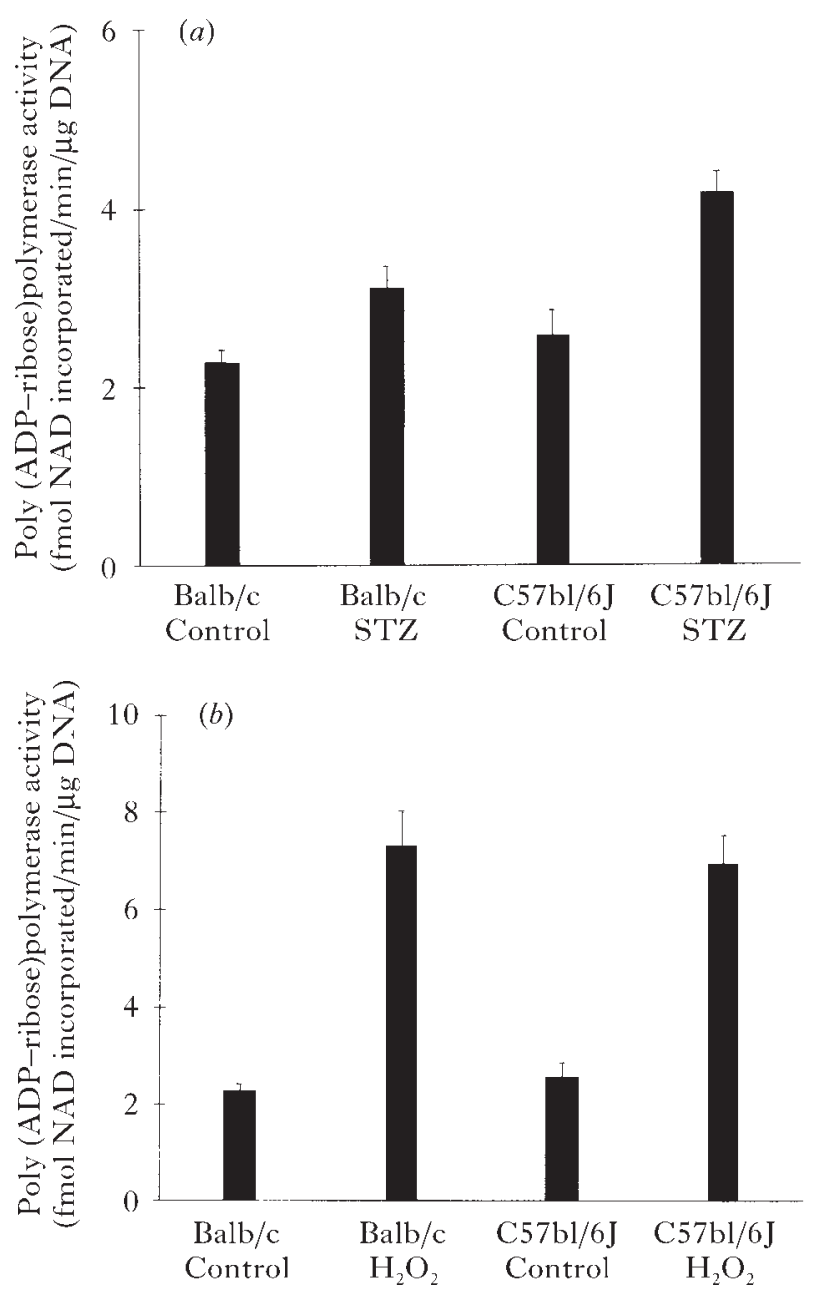

FIGURE 1. STZ and hydrogen peroxide $\left(\mathrm{H}_{2} \mathrm{O}_{2}\right)$ activation of PARP activity. (a) PARP activity was significantly increased in both Balb/c and $\mathrm{C} 57 \mathrm{bl} / 6 \mathrm{~J}$ islets treated with $2 \cdot 2 \mathrm{mM}$ STZ compared with control groups (vehicle only) $(P<0.05, P<0 \cdot 005$ respectively). STZtreated PARP activity was significantly greater in $\mathrm{C} 57 \mathrm{bl} / 6 \mathrm{~J}$ islets than in Balb/c islets $(P<0 \cdot 05)$. Each bar is the mean \pm S.E.M. of four separate experiments. The total number of mice and replicates used for each group was seven to eight. (b) There were no significant differences in PARP activation between strains in control or hydrogen-peroxide-treated islets. There was a significant difference between control and hydrogenperoxide-treated islets in both strains $(P<0 \cdot 001)$. Each bar is the mean \pm S.E.M. of four separate experiments. The total number of mice and replicates used for each group was six to eight.

proposed that the previously observed differences in islet NAD between the strains (Cardinal et al. 1998) result from differences in the rate of NAD consumption and not in the differences in NAD generation. This is likely to be the basis for the

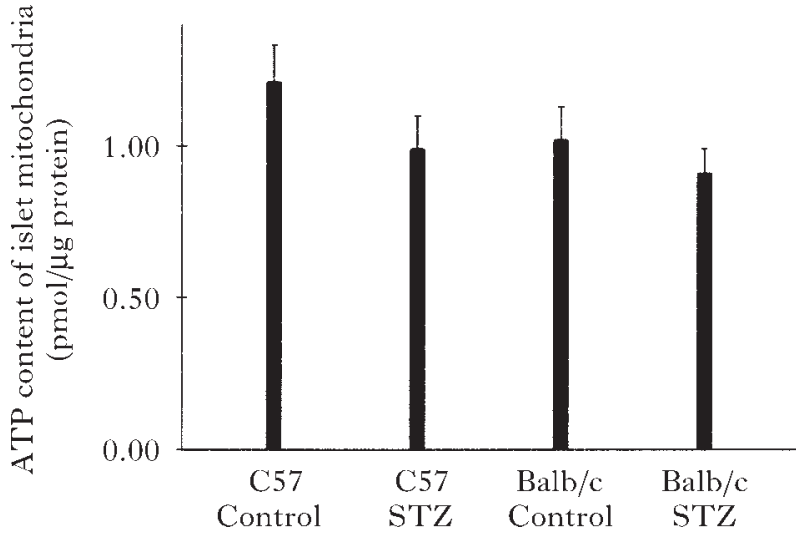

FIGURE 2. Mitochondrial ATP content of control and $2 \cdot 2 \mathrm{mM}$ STZ-treated islets. No significant differences were found between control and treated groups within strains or between strains. Each bar is the mean \pm s.E.M. of four separate experiments. The total number of mice and replicates used for each group was nine to eleven.

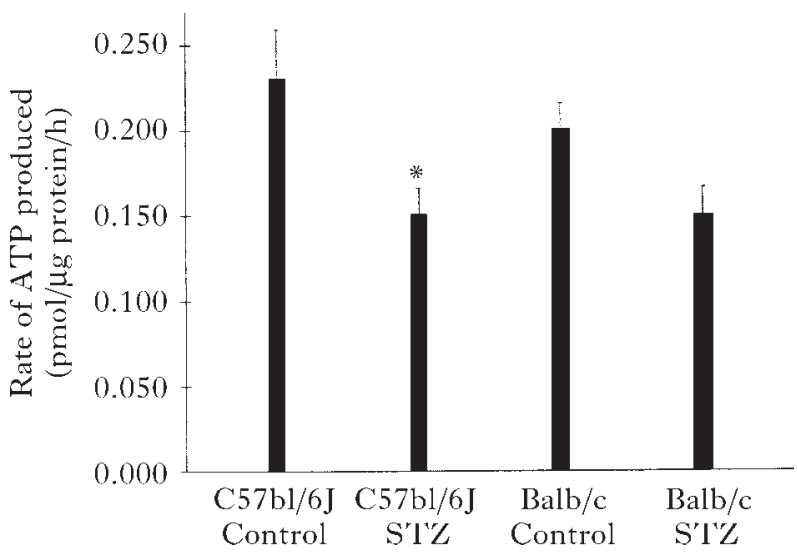

FIGURE 3. Mitochondrial activity (rate of ATP produced) of control and $2 \cdot 2 \mathrm{mM} \mathrm{STZ}$-treated islets from $\mathrm{C} 57 \mathrm{bl} / 6 \mathrm{~J}$ and Balb/c mice. There was a significant difference between control and STZ-treated groups in $\mathrm{C} 57 \mathrm{bl} / 6 \mathrm{~J}$ islets $(* P<0 \cdot 05)$. There were no significant differences in control and STZ-treated groups between strains. Each bar is the mean \pm S.E.M. of four separate experiments. The total number of mice and replicates used for each group was nine to eleven.

different sensitivity to STZ-induced diabetes between the two strains.

The greater PARP activation seen in C57bl/6J islets compared with Balb/c islets is in keeping with our previous observation of greater NAD depletion in this strain (Cardinal et al. 1998). This observation is consistent with the work of Okamoto (1982), who proposed that the primary cytotoxic effects of STZ were via the induction of DNA strand breaks and subsequent PARP activation. The results of the present study suggest that strain 


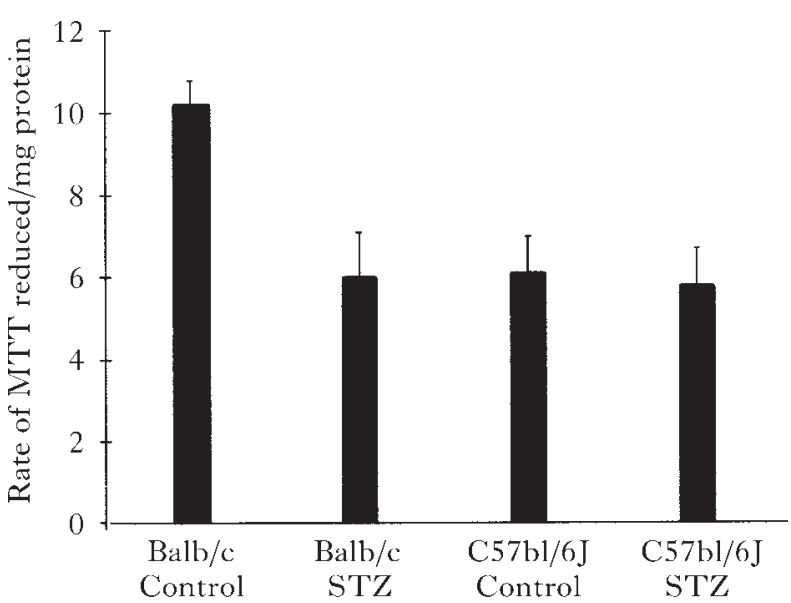

FIGURE 4. The mitochondrial activities of control and $2 \cdot 2 \mathrm{mM} \mathrm{STZ}$-treated islets as measured by the MTT dye method. There were no significant differences between $\mathrm{C} 57 \mathrm{bl} / 6 \mathrm{~J}$ control and treated islets. Control $\mathrm{Balb} / \mathrm{c}$ islets were significantly different from STZtreated Balb/c islets $(P<0 \cdot 05)$ and control $\mathrm{C} 57 \mathrm{bl} / 6 \mathrm{~J}$ islets $(P<0 \cdot 01)$. There were no significant differences between strains in STZ-treated groups. Each bar is the mean \pm S.E.M. from four separate experiments. The total number of mice and replicates used for each group was six to eight.

differences in STZ sensitivity and NAD depletion are determined by interactions at the DNA level.

PARP activation is determined by the number of DNA strand breaks present and the activity/amount of PARP enzyme (Shall 1984). It follows, then, that the observed strain variation in PARP activity must be due to the number of DNA strand breaks or the amount/activity of PARP enzyme. To exclude the latter possibility, PARP activation was measured after hydrogen peroxide treatment. STZ and other alkylating agents induce DNA strand breaks indirectly by modifying DNA bases. DNA strand breaks are caused by endonucleases during the process of DNA repair (Saffhill et al. 1985, Ledoux et al. 1986, Wilson et al. 1988). Hydrogen peroxide was used because it directly induces DNA strand breaks, without the involvement of excision repair processes (Imlay \& Linn 1988). $\beta$ cells have been reported to contain low levels of catalase and peroxidase (Eizirik 1996, Lenzen et al. 1996). Assuming this to be so, the hydrogen peroxide dose given in this study will generate approximately the same number of DNA strand breaks in both strains. Thus, with the same number of DNA strand breaks, PARP activity is proportional to the amount of enzyme present. The lack of strain difference seen in PARP activation after hydrogen peroxide treatment suggests that there is no difference in the amount/activity of PARP present in the sensitive and non-sensitive strains.

If there are no strain differences in the amount/ activity of PARP, the differences seen in STZinduced PARP activation would be due to the number of strand breaks present. It is unknown whether, at the dose given, STZ would induce DNA strand breaks directly. However, it is known that STZ induces the formation of the DNA adduct, $N-7$-methylguanine, and, to a lesser extent, O-6-methylguanine and 3-methyladenine (Saffhill et al. 1985, Ledoux et al. 1986, Wilson et al. 1988). In the process of excision repair, the damaged DNA is cut enzymically at the site of the adducts and repaired. The number of STZ-induced DNA strand breaks is determined first by the amount of DNA adducts and, secondly, by the activity of nuclear excision repair enzymes.

The present study provides evidence for the STZ-induced mitochondrial inhibition of ATP generation and, thus, inhibition of NAD production in the $\mathrm{C} 57 \mathrm{bl} / 6 \mathrm{~J}$ islets. Inhibition of mitochondrial MTT dye reduction was also demonstrated, but only in Balb/c islets. Basal levels of MTT dye reduction were lower in the $\mathrm{C} 57 \mathrm{bl} / 6 \mathrm{~J}$ strain, possibly indicating lower basal glutamate dehydrogenase activity. It would follow then that inhibition of glutamate dehydrogenase would be difficult to demonstrate in this strain. There were no strain differences detected in ATP production or electron transport chain function (as measured by MTT dye reduction) in STZ-treated islet mitochondria, indicating that the differences in NAD depletion are not due to differences in mitochondrial ATP production.

It is concluded from this study that the previously reported differences (Cardinal et al. 1998) in STZ sensitivity and NAD depletion and between $\mathrm{C} 57 \mathrm{bl} / 6 \mathrm{~J}$ and Balb/c mice are determined at the level of the DNA, and not the mitochondria. The greater PARP activation in $\mathrm{C} 57 \mathrm{bl} / 6 \mathrm{~J}$ islets is likely to be due to greater initial DNA damage, faster excision repair mechanisms, or both. Previous studies (Cardinal et al. 1998) have shown that C57bl/6J islets accumulate more STZ metabolites than do Balb/c islets. The presence of a greater level of STZ metabolite accumulation may lead to a greater level of DNA damage. Alternatively, C57bl/6J DNA adduct repair rates have previously been shown to be greater than those of Balb/c mice (Boerrigter et al. 1993), and an increased rate of DNA excision repair would cause greater levels of DNA strand breaks (Coquerelle et al. 1995). Further studies are warranted to determine the amount of DNA damage induced by STZ. 


\section{ACKNOWLEDGEMENT}

This work was funded by the Princess Alexandra Hospital Research and Development Foundation.

\section{REFERENCES}

Boerrigter M, Yin Y, Vijg J \& Wei J 1993 DNA repair in cogenic mice: possible influence of a chromosome 4 genetic region on the rate of benzo(a)pyrene DNA adduct removal. Fournal of Gerontology 48 B11-B16.

Bradford MM 1976 A rapid and sensitive method for the quantification of microgram quantities of protein utilizing the principle of protein-dye binding. Analytical Biochemistry 7 248-254.

Cardinal JW, Allan DJ \& Cameron DP 1998 Differential metabolite accumulation may be the cause of strain differences in sensitivity to streptozotocin-induced $\beta$ cell death in inbred mice. Endocrinology 139 2885-2891.

Coquerelle T, Dosch J \& Kaina B 1995 Over expression of $\mathrm{N}$-methylpurine DNA glycosylase in Chinese hamster ovary cells renders them more sensitive to the production of chromosomal aberations by methylating agents - a case of imbalanced repair. Mutation Research 336 9-17.

Eizirik DL 1996 Beta-cell defence and repair mechanisms in human pancreatic islets. Hormone and Metabolic Research 28 302-305.

Eizirik DL, Sandler S, Sener A \& Malaisse WJ 1988 Defective catabolism of $\mathrm{D}$-glucose and $\mathrm{L}$-glutamine in mouse pancreatic islets maintained in culture after streptozotocin exposure. Endocrinology 123 1001-1007.

Imlay J \& Linn S 1988 DNA damage and oxygen radical toxicity. Science 240 1302-1309.

Johansson EB \& Tjalve H 1989 Studies on the tissue-disposition and fate of $\left[{ }^{14} \mathrm{C}\right]$-streptozotocin with special reference to pancreatic islets. Acta Endocrinologica 89 339-351.

Karunanayake EH, Baker JRJ, Christian RA, Hearse DJ \& Mellows G 1976 Autoradiographic study of the distribution and cellular uptake of $\left({ }^{14} \mathrm{C}\right)$-streptozotocin in the rat. Diabetologia 12 123-128.

Kissane JM \& Robins E 1958 The fluorometric measurement of deoxyribonucleic acid in animal tissues with special reference to the central nervous system. Fournal of Biological Chemistry 233 184-188.

Kroncke KD, Fehsel K, Sommer A, Rodriguez ML \& Kolbbachofen V 1995 Nitric oxide generation during cellular metabolization of diabetogenic $N$-methyl- $N$-nitrosourea streptozotocin contributes to islet cell DNA damage. Biological Chemistry Hoppe-Seyler 376 179-185.
Kwon NS, Lee SH, Choi CS, Kho T \& Lee HS 1994 Nitric oxide generation from streptozotocin. Federation of the American Societies for Experimental Biology Fournal 8 529-533.

Lake SP, Anderson J, Chamberlain J, Gardner SJ, Bell PRF \& James RFL 1987 Bovine serum albumin density gradient isolation of rat pancreatic islets. Transplantation 43 805-808.

Ledoux SP, Woodley SE, Patton NJ \& Wilson GL 1986 Mechanism of nitrosourea-induced $\beta$ cell damage. Alterations in DNA. Diabetes 35 866-872.

Ledoux SP, Hall CR, Forbes PM, Patton NJ \& Wilson GL 1988 Mechanism of nicotinamide and thymidine protection from alloxan and streptozotocin toxicity. Diabetes 37 1015-1019.

Lenzen SL, Drinkgem J \& Tiedge M 1996 Low antioxidant enzyme gene expression in pancreatic islets compared with various other mouse tissues. Free Radical Biology and Medicine 20 463-466.

Okamoto H 1982 Molecular basis of experimental diabetes: degeneration, oncogenesis and regeneration of pancreatic B-cells of islets of langerhans. BioEssays 2 15-21.

Rossini A, Appel M, Williams R \& Like A 1977 Genetic influence of the streptozotocin-induced insulitis and hyperglycaemia. Diabetes 26 916-920.

Saffhill R, Margison GP \& O'Connor PJ 1985 Mechanisms of carcinogenesis induced by alkylating agents. Biochimica et Biophysica Acta 823 111-145.

Schein PS \& Loftus S 1968 Streptozotocin: depression of mouse liver pyridine nucleotides. Cancer Research 28 1501-1506.

Schein PS, Cooney DA, McMenamin MG \& Anderson T 1973 Streptozotocin diabetes - further studies on the mechanism of depression of nicotinamide adenine dinucleotide concentration in mouse pancreatic islets and liver. Biochemical Pharmacology 22 2625-2631.

Shall S 1984 ADP-ribose in DNA repair: a new component of DNA excision repair. Advances in Radiation Biology 11 1-69.

Uchigata Y, Yamamoto H, Kawamura A \& Okamoto H 1982 Protection by superoxide dismutase, catalase and poly(ADPribose)synthetase inhibitors against alloxan- and streptozotocin-induced islet DNA strand breaks and the inhibition of proinsulin synthesis. Fournal of Biological Chemistry 257 6084-6088.

Wilson GL, Hartig PC, Patton NJ \& Ledoux SP 1988 Mechanisms of nitrosourea-induced $\beta$ cell damage. Activation of poly(ADP-ribose)synthetase and cellular distribution. Diabetes 37 213-216.

Yamamoto H, Uchigata Y \& Okamoto H 1981 DNA strand breaks in pancreatic islets by in vivo administration of alloxan or streptozotocin. Biochemical and Biophysical Research Communications 103 1014-1020.

REVISED MANUSCRIPT RECEIVED 24 August 1998 